\title{
Gifts in Croatian public and academic libraries
}

\author{
Ivana Hebrang Grgic \\ Department of Information Sciences, Faculty of Humanities and Social Sciences, University of Zagreb, Zagreb, Croatia
}

\begin{abstract}
Purpose - The purpose of this paper is to provide information on handling gifts-in-kind in Croatian public and academic libraries. It also recommends what should be done to improve practice with gifts for collections.

Design/methodology/approach - The paper is based on the author's research conducted using an anonymous online questionnaire that was sent to Croatian public libraries $(n=139)$ and academic libraries $(n=73)$ in May 2011. After a two-week period, a total of 84 responses was received (40 public libraries and 44 academic libraries). In statistical analysis, some variables are tested by $\chi^{2}$-test to show whether differences between public and academic libraries are statistically significant.

Findings - The majority of Croatian libraries do not have gift policy statements. Gifts do have a significant part in collection building, especially in Croatian academic libraries, but are not always handled in the right way (i.e. according to IFLA's guidelines). This paper shows the quantity of gifts in the libraries, librarians' reasons for not accepting some gifts, librarians' methods in dealing with gifts, and their way of communicating with donors or potential donors.

Originality/value - This paper gives results of the first complete study of gift policies in Croatian public and academic libraries. In conclusion, a need for a written gift policy in Croatian libraries is emphasized and some recommendations are given.
\end{abstract}

Keywords Gifts, Library collections, Croatia, Public libraries, Academic libraries

Paper type Research paper

\section{Introduction}

Gifts are an important component of collection building in libraries. Gifts can come from various sources - they can be very valuable and useful for a library and its users, but they can also be redundant, or even expensive for the library they are given to. That is the main reason why libraries should have specific guidelines for soliciting and accepting gifts for their collections. If we look back in history, we can find numerous examples of gifts that were the basis for funding some famous libraries, such as the Biblioteca Marciana in Venice or Harvard libraries (Kohl, 2010). Sir Thomas Bodley, the (re)founder of the Bodleian library in Oxford (that was also originally founded as a gift from Humphrey, Duke of Gloucester in 1470 but was abandoned until 1598), understood the importance of gifts and donations for library collections. He created a Benefactors' Book in 1602 "in which the name of every benefactor should be written down in a large and fair hand so all might read. And he kept the register prominently displayed so that no visitor to the library could escape seeing the generosity of Bodley's friends" (Wright, 1939). In this paper we will analyse gift policies in Croatian public and academic libraries. Gifts for libraries can be inkind or cash donations. Although both kinds of donations are valuable for libraries, gifts-in-kind (cash donations) are very rare in Croatian libraries.

The current issue and full text archive of this journal is available at www.emeraldinsight.com/0160-4953.htm

Collection Building

30/4 (2011) 167-171

(c) Emerald Group Publishing Limited [ISSN 0160-4953]

[DOI 10.1108/01604951111181137]
A short literature review will try to prove the importance of gifts for collection building, but also the importance of written guidelines that are necessary if libraries want to build their collections according to their collection development policies. Results of an online survey of Croatian libraries will show the practice in Croatian libraries - how they solicit and accept gifts; if they have written guidelines; if gifts are important for their collection development; how many unsolicited gift offers they receive; what do they do with unwanted gifts.

The results will also show if there are some differences in dealing with gifts between Croatian public and academic libraries. Based on the results, some recommendations for further practice will be proposed.

\section{Literature review}

Many information specialists have discussed problems connected with gifts for library collections. We will here give a short overview of some literature published in the last two decades.

Buis (1991) states that gifts are never really free of charge; they cost the library time and money and also can create problems if they are unwanted. Buis mentions marginal gifts that are out of scope of library's collection development policy. A perfect librarian must not allow the human side of graceful acceptance to prevail, he has to act according to a written gift policy to save time and money for his/her library. The hidden costs associated with handling unsolicited gifts are also discussed by Johnson (1993a) and Dickinson (1997). Johnson (1993b) wrote another article discussing how tricky negotiations with library donors can be. Formal gift acceptance policies should be created by libraries to avoid

Received 26 July 2011

Accepted 29 July 2011 


\section{Ivana Hebrang Grgic}

misunderstandings and improve negotiating methods. Johnson encourages libraries not to accept conditional donations, especially if the donors restrict libraries in how they process or dispose of the materials.

The importance of a library gift policy was also stressed by Pearson and Crockett (1994). Inadequate library collections are described by Mills (1994). She focused on several South Pacific libraries with limited budgets. The libraries depended on gifts, but Mills says that gifts should not be a primary method for collection development.

Strnad (1995) wrote about unsuitable donations. Librarians have always been looking to increase their collections without spending any money. The approach can result in building collections that are out of scope of libraries' collection development policies. Some donors have the sole goal to get rid of books and other materials and that is why libraries must have collection development policies explaining what materials they collect.

Leonhardt (1997) published the results of his survey of 60 American research libraries proposing that there had been many changes in gift and exchange operations during the last two decades. He was aware of the continuous rise of publication costs and believed that gifts would become an even more important way of collection building.

A very useful source for studying twentieth century literature on gifts for library collections is Carrico's bibliography with 48 annotated sources dating from the last three decades of the century. The author divided the bibliography into five sections defining the five major topics when discussing gifts for library collections - gift (and exchange) programs, gift donations and acceptance policies, gift processing and collection development, disposal of unwanted gifts, and gift appraisals and tax laws (Carrico, 1999).

Kairis (2000) compared usage of gift materials and materials selected and purchased by a small academic library. The results showed that donated books were used on average 0.9 times within a year, whereas purchased books were used 1.4 times. That should be the reason for reevaluating current gift policies in the library. McKee (2003) wrote about planned gifts. They are defined as gifts that conform to goals of the donor's formal plan regarding their finances. Planned gifts can maximize the funding that libraries receive. Massey (2005) provided useful guidelines for handling gifts to an academic library so that they can easily be retrieved and the donor can see how the library is handling the donation.

Bishop et al. (2010) wrote about refocusing a gift program in Colorado State University Libraries. The libraries decided to eliminate their general gift program. The authors commented on the efforts to formulate and implement a new policy on gift acquisitions.

An excellent starting point for a library gift policy can be IFLA's publication, Gifts for the Collections - Guidelines for Libraries (Cassell et al., 2008). In the document, a gift policy statement for internal use by staff is discussed, as well as handling unsolicited gifts, negotiations for solicited gifts, evaluating gifts, resource requirements considerations and acknowledgement of gifts. The publication was translated and published in Croatia in 2010 and resulted in raising awareness among librarians about the importance of writing gift policies for libraries.

According to the literature, gifts are valuable for library collections, but they must not be accepted without selections that meet the standards described in library's collection development policy. Each library should have such a policy. Also, based on the policy, guidelines for handling gifts could be helpful for collection building in libraries.

\section{Survey of Croatian public and academic libraries}

An online questionnaire was sent to all the Croatian public and academic libraries. Libraries' e-mails were found at three web locations. E-mails of public libraries were found at the portal of Croatian public libraries (www.knjiznica.hr/ home.php) as well as at Croatian Ministry of Culture website (www.min-kulture.hr/default.aspx?id = 202). At the same website e-mails of academic libraries were found and the list was extended with e-mails of libraries in scientific institutions found on the Croatian Ministry of Science, Education and Sports website (www.mzos.hr/ustanove/ pregled.aspx?order $=1$ ). The final list consisted of the emails of 139 public libraries (excluding 26 invalid e-mails) and 73 academic libraries (excluding five invalid e-mails). The anonymous questionnaire was sent to all the 212 e-mails and, by the end of May 2011 there were 84 complete responses ( 40 from public and 44 from academic libraries). Response rate for all the libraries was 39.6 per cent (29.6 per cent for public and 60.3 per cent for academic libraries). The first difference between the two kinds of libraries can be seen immediately; the response rate is twice as higher for academic libraries.

The questionnaire consisted of 13 questions; it was created using a free online version of survey software. The purpose of the survey was to find out several important issues on libraries' gift policies: approximate quantity of gifts-in-kind in acquisition, usual number of donated items in one donation, existence of written gift policies in libraries, different gifts procedures (offering gifts, rejecting gifts, acknowledgements), reasons for in-kind donations, reasons for refusing unsolicited gifts, conditional in-kind donations and other issues.

\section{Statistical analysis}

As gifts are one of the methods of acquisition in libraries, the first question was about approximate percentage of gifts in annual acquisition. Results showed that academic libraries have a higher percentage of gifts - in 59 per cent of academic libraries and in 32.5 per cent of public libraries more than 10 per cent of acquired items (any material type) every year are gifts. The average number of donated items in one donation is higher for public libraries - 62.5 per cent of them receive more than five items per donation, and 45.5 per cent academic libraries receive more than five items per donation. The value of the items can be variable, of course, so the next question was - did you have, in the last two years, examples of valuable donations. A total of 24.4 per cent of academic libraries and five per cent of public libraries answered affirmatively. We can conclude that public libraries receive more gifts, but the value of donated items is higher in academic libraries.

Donators' reasons for donating materials are interesting. Table I shows donators' reasons for donating materials to 
Table I Reasons for donating materials ranged from the most usual to the most unusual

\begin{tabular}{ll}
\hline No. & Reason \\
\hline 1 & $\begin{array}{l}\text { Donors want to get rid of materials they do not need } \\
\text { Donors want to donate materials that will be useful for the } \\
\text { library and its users }\end{array}$ \\
3 & $\begin{array}{l}\text { Exchanges for lost items } \\
\text { Sensitive materials that donor cannot store in appropriate } \\
\text { conditions } \\
\text { Bequests }\end{array}$ \\
\hline
\end{tabular}

libraries from the most usual (no. 1) to the most unusual (no. 5). The scale is the same for both kinds of libraries.

Gifts for library collections can be solicited or unsolicited. The fifth question asked if the library accepts all gifts, regardless of their value or compliance with collection development policy. When we analyse the answers, we have to have in mind the differences between users (and donors) of the two kinds of libraries. Users of academic libraries are scientists and/or students, and when they chose to donate materials, they are more likely to know what their libraries' specific needs are. So 34.1 per cent of academic libraries and 22.5 per cent of public libraries accept all gifts. If a library does not accept all gifts, the question is how it refuses unwanted gifts. Answers to the sixth question which was multiple choice show that 17.5 per cent of public libraries and 31.7 per cent of academic libraries write a letter to explain why the gifts cannot be accepted.

Negotiations for solicited gifts should be done by authorised employers who represent the library and can appropriately solicit gifts for the collections. Asked if they had an authorised employee who represented the library in informal and formal negotiations for gifts, 25 per cent of public libraries and 34.1 per cent of academic libraries answered affirmatively.

Libraries usually discourage conditional donations and express (or should express) this as part of their policy statement. Exceptions to this rule can, of course, apply to avoid discouraging potentially valuable gifts. In Croatia, 10 per cent of public libraries and 22.7 per cent of academic libraries accept conditional donations. Asked (in the ninth question) to write examples of conditions, some of them answered:

- there should be no access restrictions (an academic library);

- a local sports organisation donated library materials, condition was free library membership for the members of the organisation (a public library);

- donated items have to be housed together (two academic libraries);

- access can only be made available to onsite users (an academic library); and

- a bookplate acknowledging the donor should be attached to the donated items (two academic libraries).

Acknowledgment of gifts is another important issue when discussing gifts for library collections. A letter of appreciation should be sent to each donor. In Croatia, 65 per cent of public libraries and 93.2 per cent of academic libraries send written acknowledgment for each donation (Figure 1).

To minimise all the possible problems that could be caused by receiving unsolicited gifts, conditional gifts, inappropriate and impolite acknowledging etc., libraries should develop guidelines as to what gifts will be accepted and what gifts will not be accepted into their collections. The guidelines should be based on their collection development policy. Libraries should accept gifts that meet the same standards or selection criteria used for materials purchased for the collections. The 11 th question asked whether the library has a written document that defines what gifts will be accepted. A total of 30 per cent of public libraries and 34.1 per cent of academic libraries answered affirmatively. Asked to specify the document, 7.5 per cent public libraries and 11.4 per cent academic libraries answered that they have a stand-alone document that defines gift policy. Other libraries that answered affirmatively to the question as to whether they have broader documents (e. g. collection development policy)

Figure 1 Does the library send letters of appreciation to donors?

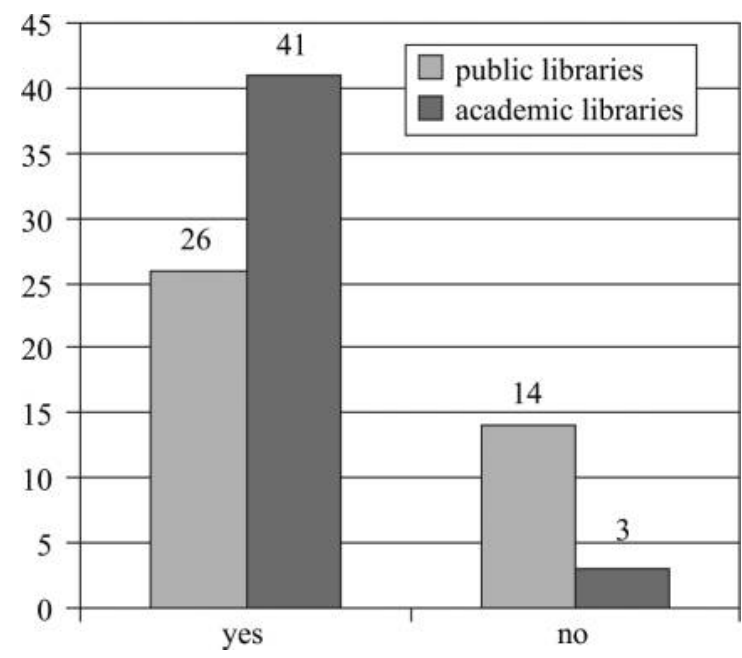

Figure 2 Does the library have gift policy statement (as a stand-alone document)?

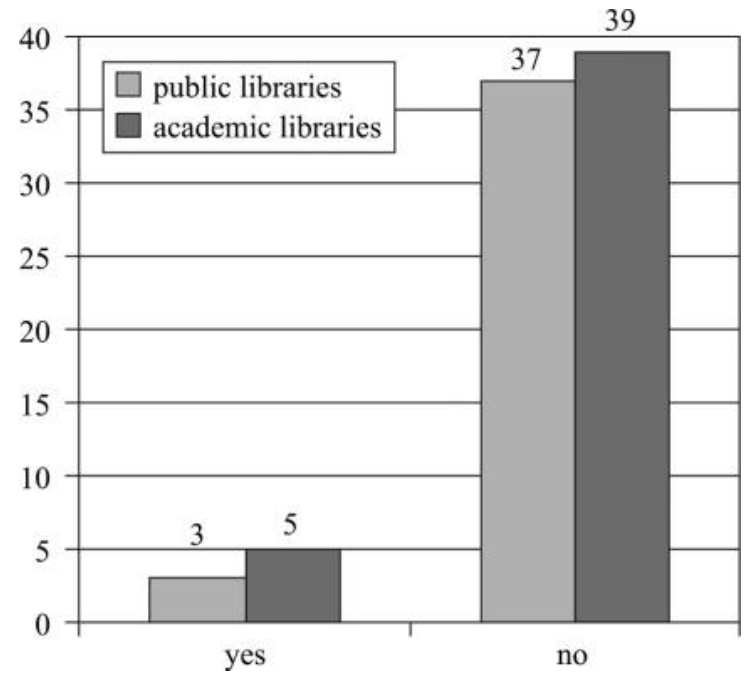


Table II Differences between Croatian public and academic libraries in handling gifts

\begin{tabular}{|c|c|c|c|}
\hline & $\begin{array}{c}\text { Public libraries } \\
(n=40)(\%)\end{array}$ & $\begin{array}{c}\text { Academic libraries } \\
(n=41)(\%)\end{array}$ & $\mathrm{P}\left(\chi^{2}\right.$ test $)$ \\
\hline Percentage of gifts in annual acquisition higher than 10 per cent & 32.5 & 59 & 0.015 \\
\hline No. of donated items in one donation higher than 5 & 62.5 & 45.5 & 0.118 \\
\hline Gift policy statement & 7.5 & 11.4 & 0.547 \\
\hline Library accepts all gifts & 22.5 & 34.1 & 0.240 \\
\hline Valuable donations in the last 2 years & 5 & 22.7 & 0.014 \\
\hline Authorised employees for negotiations & 25 & 34.1 & 0.363 \\
\hline Acceptance of conditional donations & 10 & 22.7 & 0.118 \\
\hline Letters of acknowledgment & 65 & 93.2 & 0.001 \\
\hline
\end{tabular}

that define, among some other issues, gift policies (Figure 2). It would be useful if every library would publish instructions to the public concerning unsolicited gifts. The instructions could encourage gifts but also explain that only material that complements current library collections and goals can be accepted. Also, libraries should recommend that the donor supply a list of the items rather than send the items themselves. In 25 per cent of public libraries and in 56.8 per cent of academic libraries some donors supply lists of items.

Some of the variables described above, were tested by the $\chi^{2}$-test to show whether differences between public and academic libraries are statistically significant (with $p<0.05$ considered statistically significant). In Table II statistically significant variables are written in italic letters.

\section{Conclusion}

What are the differences between Croatian public and academic libraries when handling in-kind-gifts for their collections? First of all, academic librarians were more willing to answer the questions. Three variables with proven statistical differences between the two kinds of libraries are percentage of gifts in annual acquisitions, valuable donations in the last two years and sending letters of appreciation. We can see that gifts in Croatian academic libraries are a more important way of collection building. They add more gifts to the collections as older and historical materials are more valuable for them than for public libraries. There are also more valuable donations in academic libraries than in public libraries. That can be explained by the users' profile. Academics usually donate materials that are important to their libraries. Academics are also more likely to know what material is interesting to their colleagues, i.e. other users of their libraries. Valuable donations could be encouraged, in both kinds of libraries, by a written document that defines gift policy. Academic libraries are more aware of the importance of sending letters of appreciation in response to every donation. Beside the fact that it is polite to thank donors for gifts, the letters are a way of tracking data on donors and potential future donors as well as a way of encouraging donors to make new donations. A written gift policy could specify the text of letters of appreciation.

The lack of gift policy statements is characteristic of both kinds of libraries. Although some of them define gift policy as a part of their collection development policy and although a minority of libraries do have a gift policy statement, there are still a great number of libraries without any document defining the handling of gifts. The lack of policy could be the problem in some specific situations, such as inappropriate offers, problems with ownership, sensitive materials or donors' special conditions. Solutions to all the possible problems should be anticipated in an official library gift policy statement. The document should be publicly available as to avoid misunderstandings when communicating with donors. Besides, the document could encourage offers and facilitate acquiring, processing, organising and preserving donated materials.

The two most important documents that the gift policy should be based on are annual reports of each library (or other documents that keep tracks of donations), and IFLA's publication, Gifts for the Collections, that documents best practices for libraries around the world. As stated in the introduction of the publication, gifts are free of purchase costs, but are not costless to the receiving library. It seems like the Croatian translation of the publication initiated some activities in Croatian libraries towards building gift policies. It would be interesting to repeat the survey in few years as to see the changes and possible improvements.

\section{References}

Bishop, J., Smith, P.A. and Sugnet, C. (2010), "Refocusing a gift program in an academic library", Librarv Collections, Acquisitions, and Technical Services, Vol. 34 No. 4, pp. 115-22.

Buis, E. (1991), "Killing us with kindness or what to do with those gifts", Collection Building, Vol. 11 No. 2, pp. 10-12.

Carrico, S.B. (1999), "Gifts in academic and special libraries: a selected bibliography", Library Collections, Acquisitions, and Technical Services, Vol. 23 No. 4, pp. 421-31.

Cassell, K.A., Johnson, S., Mansfield, J. and Zang, S.L. (2008), Gifts for the Collections: Guidelines for Libraries, IFLA Headquarters, The Hague.

Dickinson, D.W. (1997), "Free books: are they worth what they cost?", Library Issues, Vol. 17 No. 5, pp. 1-4.

Johnson, P. (1993a), "When to look a gift horse in the mouth", Technicalities, Vol. 13, June, pp. 10-13.

Johnson, P. (1993b), "Grace under pressure: relations with library donors", Technicalities, Vol. 13, August, pp. 5-9.

Kairis, R. (2000), "Comparing gifts to purchased materials: a usage study", Library Collections, Acquisitions, and Technical Services, Vol. 24 No. 9, pp. 351-9.

Kohl, D.F. (2010), "Collection development in the ARL library", Encyclopedia of Library and Information Sciences, 3rd Ed., Taylor \& Francis, London. 
Leonhardt, T.W. (1997), "The gifts and exchange function in ARL libraries: now and tomorrow", Librarv Acquisitions: Practice and Theorv, Vol. 21, Summer, pp. 141-9.

McKee, J. (2003), "What every library can (and should) do to increase private support through planned gifts", The Bottom Line: Managing Librarv Finances, Vol. 16 No. 4, pp. 151-3. Massey, T. (2005), "Management of gift materials in an academic library”, Collection Building, Vol. 24 No. 3, pp. 80-2.

Mills, C. (1994), "Aid for libraries: should one look the proverbial gift horse in the mouth?", Australian Academic and Research Libraries, Vol. 25, December, pp. 240-6.

Pearson, R.C. and Crockett, A. (1994), "Gifts to the library, boon or bust: does your library have a policy?", Idaho Librarian, Vol. 46, July, p. 82.
Strnad, B. (1995), "How to look a gift horse in the mouth, or how to tell people you can't use their old junk in your library", Collection Building, Vol. 14 No. 2, pp. 29-31.

Wright, L.B. (1939), "Some early 'friends' of libraries", The Huntington Library Quarterly, Vol. 2 No. 3, available at: http://links.jstor.org/sici?sici=0018-7895\%28193904\% $292 \% 3$ A3\%3C355\%3ASE\%22OL\%3E2.0.CO\%3B2-B (accessed 5 May 2011).

\section{Corresponding author}

Ivana Hebrang Grgic can be contacted at: ivana.grgic@ffzg.hr

To purchase reprints of this article please e-mail: reprints@emeraldinsight.com Or visit our web site for further details: www.emeraldinsight.com/reprints 
This article has been cited by:

1. Aubrey Harvey Chaputula, Allan James Kanyundo. 2014. Collection development policy: How its absence has affected collection development practices at Mzuzu University Library. Journal of Librarianship and Information Science 46:4, 317-325. [Crossref]

2. Joseph A. Williams. 2014. Is Trash a Library's Treasure? A Study of Gifts-in-Kind Practices and Policies Among New York State Libraries. Library Collections, Acquisitions, \& Technical Services 38:1-2, 1-9. [Crossref] 